\title{
Refratometria ou Optometria?
}

\author{
Harley E. A. Bicas* \\ Elisabeto Ribeiro Gonçalves ${ }^{* *}$
}

Deliberadamente provocativo, o título confronta como excludentes dois termos comumente tomados com mesmo sentido (o da medida das condições ópticas do olho), mas, ultimamente, com implicações políticas bem distanciadas dos significados semânticos bem parecidos. Pois é justamente numa vertente polêmica de polarização que serão diferenciados esses dois modos de se avaliar o estado da refração ocular.

De começo, convém relembrar que o sistema óptico ocular é ativo, suas medidas variando de acordo com os ajustamentos produzidos pelo mecanismo da acomodação. Desenvolveramse, então, dois métodos de avaliação do estado de adequação óptica do olho: um sem que esse mecanismo esteja neutralizado (a chamada refratometria "dinâmica"), o outro quando ele for impedido (a chamada refratometria "estática”).

Ora, a função acomodativa é regulada pelo sistema nervoso autônomo que, como o próprio nome indica, não se subordina a comandos volitivos. Depende de mecanimos reflexos, como os dos movimentos peristálticos do intestino, os da taquicardia e da mão fria e suarenta na iminência da entrevista decisiva. $\mathrm{O}$ problema está em que a técnica principal com que se tenta conseguir o repouso acomodativo de uma pessoa é a de que ela veja a imagem de um objeto fixado sem nitidez, como "através de uma névoa" (o chamado "fogging"). Curiosamente, entretanto, borramento ou enevoamento das imagens, o escuro, o "vazio" óptico são, por si próprios, evocadores da acomodação e não seus relaxantes. Portanto, e paradoxalmente, ao se procurar o repouso funcional do músculo ciliar por esse método, o que se consegue é ação acomodativa reflexa. E é de conhecimento notório que essa resposta pode chegar a valores freqüentemente superiores a uma dioptria. De resto, há casos (e não são raros) em que se tem o chamado "espasmo acomodativo" (justamente pelo uso persistente da função acomodativa) tornando inviável um relaxamento eficaz do músculo ciliar, o que propicia diagnósticos de miopia quando ela inexiste, ou de menor hipermetropia. Com eventuais prescrições, decorrentes, que perpetuariam e agravariam o quadro espástico. Na verdade, o único modo de se garantir o relaxamento completo da acomodação é o por via farmacológica, com drogas cicloplégicas, parassimpaticolíticas.

Mas além desse erro relacionado como do "componente esférico" do sistema óptico ocular, torna-se ainda possível o

\footnotetext{
${ }^{*}$ Editor Chefe - Arquivos Brasileiros e Oftalmologia

** Presidente do Conselho Brasileiro de Oftalmologia
}

da medida do eventual astigmatismo, tanto em magnitude (valor dióptrico do componente cilíndrico da ametropia) quanto em direção (posição do eixo de sua correção relativamente ao do olho). De fato, como dois meridianos oculares, perpendiculares entre si, devam ser sempre estudados no estudo refratométrico do olho e como erros são inerentes a quaisquer mensurações, embora considerando-se diferenças mínimas (da ordem de 0,25 D) para mais ou para menos em cada uma, oito outras combinações são possíveis.

Dessas, pelo menos quatro, as que supõem a possibilidade de comparações com a adição de valores negativos, suscitarão a resposta acomodativa, comprometendo a qualidade da informação subjetiva. Aliás, se a um jovem emétrope, na plena capacidade de ajustamento acomodativo, for realizado um teste subjetivo de "ajustamento" de lentes, sem cicloplegia, a indicação da preferida ficará entre uma de $-0,50$ a -1,00 D na fixação para longe e de $+0,50 \mathrm{a}+1,00 \mathrm{D}$ na para perto. Esse exame, se fosse tomado para valer, suscitaria prescrições de -0,50 a -1,00 D sf para longe, com adições de $+1,00 \mathrm{a}+2,00 \mathrm{D}$ sf para perto!

Em resumo, a cicloplegia é essencial para assegurar a aferição exata da adequação refracional do olho, isto é, do eventual estado de ametropia e de seus valores: tanto pelo repouso completo do mecanismo acomodativo (e lembre-se que a própria definição de ametropia exige essa condição) quanto pela facilitação de testes complementares. Pois, efetivamente, a medida do estado refratométrico ocular depende de duas avaliações: uma objetiva, realizada sem a colaboração do examinado (pela retinoscopia, ou por técnicas equivalentes, inclusive as automatizadas) e a subjetiva em que se torna possível o refinamento dos valores instrumentais. Ainda, em outras palavras, a cicloplegia torna-se exigível em crianças e não-informantes, porque não colaboram em quaisquer dos procedimentos com que se pretenderia relaxar-lhes a acomodação; e em pessoas boas informantes, justamente porque podem ajudar com a parte subjetiva da refratometria, aperfeiçoando-a.

Por outro lado, as razões pelas quais a cicloplegia deveria ser evitada parecem inconsistentes: porque o paciente fica sem acomodação (como se o período relativamente curto desse impedimento não justificasse o conhecimento exato da ametropia, necesário para uma boa prescrição; que aliás, chega a durar anos); porque o colírio cicloplégico incomoda (como se a sensação de ardor não pudesse ser evitada com agentes anestésicos); porque a pupila se dilata (como se isso não fosse importante para um bom exame do fundo do olho e 
como se isso não ajudasse no teste subjetivo, aumentandolhe a precisão, pela menor profundidade de foco e de campo, no teste subjetivo); porque o paciente pode não gostar (como se conviesse perguntar a um diabético requerendo aplicações de insulina se gosta delas), porque o paciente não quer esperar o tempo para efeito cicloplégico (como se este não fosse alcançado em poucos minutos).

É claro que, como drogas parassimpaticolíticas, os agentes cicloplégicos mostram efeitos colaterais, principalmente em crianças: vasodilatação periférica (como rubor e aumento da temperatura cutânea) e taquicardia, sonolência ou irritabilidade (e em dosagens maiores, torpor ou agitação), alucinações (dosagens excessivas) e até complicações cardio-respiratórias mais sérias (envenenamento). Pode, ainda, causar bloqueio pupilar e uma crise de glaucoma. Por isso mesmo, esses agentes só devem ser empregados por médicos, não sendo facultado seu uso a outros.

E daí, a conclusão: há um modo apropriado para se conseguir com segurança e exatidão o valor da refratometria ocular; e esse modo, com a garantia do relaxamento completo do mecanismo acomodativo e com as contraprovas subjetivas (quando aplicáveis) para eliminação de possíveis erros remanescentes (inerentes a quaisquer medidas) exige a cicloplegia. Cujo uso exige cuidado e conhecimentos sobre a aplicação e o efeito de drogas. É pois um ato médico. Ao outro método, pode-se chamar optometria.

E agora, sim, podemos voltar ao princípio. Refratometria e optometria não são, pois, métodos alternativos de estudo (adequado) da óptica ocular: um é, o outro não. Um busca a perfeição; o outro contenta-se com a feição...

Um médico poderia, eventualmente, optar por não usar drogas em seus exames ou tratamentos, mas o oposto é vedado a paramédicos. Um psicólogo não tem permissão para prescrever psicotrópicos, nem um fisioterapeuta está autorizado a medicar alguém para fazer-lhe diagnóstico de miastenia grave. Assim, também, um óptico, por mais bem informado que fosse em questões de refração ocular, não poderia realizar suas medidas do modo como elas devam ser per-feitas.

Paradoxalmente, não tem sido enfaticamente usada como argumento essa questão substantiva, diferenciando o que o oftalmologista tem como um atributo de seu núcleo de competência para a refratometria ocular: o uso de agentes cicloplégicos, parassimpaticolíticos. Com esse trunfo, ficar discutindo que há oftalmologistas de sobra para dar conta do que outros pretenderiam (inadequadamente) tentar fazer; ou que há mais autoridade e saber na formação médica que na de eventuais optometristas (o que é verdade), não chega a ser perda de tempo, mas desgasta. Afinal, o que está em jogo não é uma defesa corporativista de uma "reserva de mercado" para oftalmologistas. O que está em pauta é a aplicação de um procedimento que para ser realizado segundo sua própria definição, fundamento e propósito, requer o rigor de um "ato médico" (com a exigida contrapartida de responsabilidades), dando-se como alternativa que ele possa ser feito na base da improvisação, ainda que experimentada. 